\title{
Decontamination of genetically modified mice strains by embryo transfer for obtaining SPF colonies in a Brazilian animal facility
}

\author{
Descontaminação de linhagens de camundongos geneticamente \\ modificadas por transferência embrionária para obtenção de colônias \\ SPF em um biotério brasileiro (São Paulo, SP)
}

\author{
Ana Tada Fonseca Brasil Antiorio ${ }^{1 *}$ (D); Sílvia Maria Gomes Massironi²; Rosália Regina De Luca ${ }^{2}$; \\ Márcio Augusto Caldas Rocha Carvalho ${ }^{2}$; Vanessa Yamamoto Tambellini²; Danilo Wadt ${ }^{1}$; Juliana Bortolatto ${ }^{3}$; \\ Joana Bom ${ }^{4}$; Claudia Madalena Cabrera Mori ${ }^{1}$

\footnotetext{
${ }^{1}$ Universidade de São Paulo, Faculdade de Medicina Veterinária e Zootecnia, Departamento de Patologia, São Paulo - SP, Brazil ${ }^{2}$ Universidade de São Paulo, Instituto de Ciências Biomédicas, Biotério de Camundongos Isogênicos, Departamento de Imunologia, São Paulo - SP, Brazil São Paulo - SP, Brazil

${ }^{4}$ Instituto Gulbenkian de Ciência (IGC), Oeiras - Portugal
} \\ ${ }^{3}$ Universidade de São Paulo, Faculdade de Medicina, Laboratório de Controle de Qualidade Genética e Sanitária do Centro de Bioterismo,
}

\begin{abstract}
The introduction of new strains of mice in specific pathogen-free (SPF) animal facilities should be performed carefully to avoid breaking sanitary barriers. To meet this need, animals should be rederived to reduce infection risk and thus avoid research interference caused by loss of animal health status and welfare. The objective of this study was to implement mice embryo transfer in the laboratory mouse facility of the Department of Immunology at the Institute of Biomedical Sciences/University of São Paulo, Brazil. Embryo transfers were performed to rederive genetically modified mouse strains with undefined sanitary status, received from different research and educational institutions. Fertilized eggs at two-cell stage were obtained by natural means and transferred into the oviducts of SPF pseudo-pregnant female mice. All surgical procedures were performed under aseptic conditions. A total of 625 embryos were transferred into the recipients. 148 pups were born, of which 140 were reared. Viruses, bacteria and intestinal protozoa were eliminated using this technique. The improvement in the microbiological status of mice allowed their expansion in our SPF facility. With these results, we can stimulate the use of embryo transfer technique between rodent facilities in Brazil and thus encourage the distribution of better models to our scientific community.
\end{abstract}

Keywords: Strains rederivation. Animal reception. Cleaning colonies. Assisted reproduction. Mouse embryos.

\section{RESUMO}

A introdução de novas linhagens de camundongos em biotérios livres de patógenos específicos (SPF) deve ser realizada com critérios para evitar a quebra das barreiras sanitárias. Dessa forma, os animais devem ser rederivados para reduzir os riscos de infecção e evitar as interferências provocadas pela perda do status sanitário e do bem-estar dos animais. O objetivo deste estudo foi implementar a transferência de embriões murinos no Biotério do Departamento de Imunologia do Instituto de Ciências Biomédicas da Universidade de São Paulo, Brasil. As transferências embrionárias foram realizadas para rederivar linhagens de camundongos geneticamente modificadas com status sanitário não conhecido, recebidas de diferentes instituições de pesquisa e de ensino. Os embriões em duas células foram obtidos pelos métodos naturais e transferidos para os ovidutos de fêmeas de camundongos SPF pseudoprenhas. Todos os procedimentos cirúrgicos foram realizados sob condições assépticas. Um total de 625 embriões foram transferidos para as receptoras. Foram obtidos 148 filhotes nascidos vivos, destes 140 foram desmamados. Por meio desta técnica, foram eliminados vírus, bactérias e protozoários intestinais. A melhora no status microbiológico dos camundongos permitiu a expansão destes em nossa colônia SPF. Com esses resultados, podemos promover o uso da técnica de transferência de embriões entre os biotérios brasileiros e assim incentivar a distribuição de modelos mais adequados para a nossa comunidade científica.

Palavras-chave: Rederivação de linhagens. Recepção de animais. Limpeza de colônias. Reprodução assistida. Embriões murinos. 
Correspondence to:

Ana Tada Fonseca Brasil Antiorio

Universidade de São Paulo, Faculdade de Medicina Veterinária

e Zootecnia, Departamento de Patologia

Av. Prof. Dr. Orlando Marques de Paiva, 87 - Cidade

Universitária

CEP: 05508-270, São Paulo - SP, Brazil

e-mail: anatbrasil@usp.br

Submited: February 19, 2018

Approved: December 14, 2018

How to Cite: Antiorio ATFB, Massironi SMG, De Luca RR, Carvalho MACR, Tambellini VY, Wadt D, Bortolatto J, Bom J, Mori CMC. Decontamination of genetically modified mice strains by embryo transfer for obtaining SPF colonies in a Brazilian animal facility. Braz J Vet Res Anim Sci. 2019;56(1): e143588. https://doi.org/10.11606/ issn.1678-4456.bjvras.2019.143588

\section{Introduction}

Transfer of animals and germplasm between research rodent facilities may cause the dissemination of pathogenic agents with the consequent impact on the animal's health and on the research development (Baker, 1998; Fray et al., 2008; Mahabir et al., 2008). Because of this, the introduction of new mouse strains into specific pathogen free (SPF) facilities should be performed by rederivation techniques that lead to animals with defined microbiota status (Inzunza et al., 2005).

Rederivation may be performed on laboratory rodent species by different methodologies, such as transfer of pre-implantation eggs, hysterectomy, fostering and cross-fostering (Watson et al., 1977; Davis, 1981; Rouleau et al., 1993; Watson et al., 2005; Glage et al., 2007; Compton, 2008).

Pre-implantation embryos obtained by natural means or by in vitro fertilization are surgically transferred into the oviducts of recipients that are axenic or free of specific pathogens. Transfer of embryos in early stages of development is considered effective to eliminate diseases caused by different pathogens that affect naturally or experimentally infected mice. In addition, rederivation associated with strict sanitary barriers, enables maintenance of mouse colonies free from infectious agents over the long-term (Stehr et al., 2009; Nicklas et al., 2015).

Transfer of in-vivo-derived embryos can effectively limit the spread of infectious diseases between populations of livestock (Stringfellow \& Givens, 2000). Furthermore, rederivation of mouse strains by fresh embryo transfer has been reported to avoid vertical transmission of mouse diseases (Reetz et al., 1988). The risk of transmission of certain viruses by embryo transfer, such as murine parvoviruses, should always be considered, though this technique reduces the potential for the introduction of diseases into animal facilities (Janus et al., 2009).

Within the context of the 3 R's in animal experimentation, rederivation promotes reduction in the number of animals to be used in each study and refinement, due to the use of animals with a defined sanitary standard (Russel \& Burch, 1959; Morrell, 1999).

The present work describes the implementation of embryo transfer to rederive genetically modified mouse strains at the animal facility of the Department of Immunology of the Institute of Biomedical Sciences of the University of São Paulo (ICB/USP) in Brazil. We present the reproductive outcome, sanitary controls, and the most relevant subjects in the technical issues.

\section{Materials and Methods}

\section{Laboratory animal facility: ambient conditions and animal husbandry}

The mouse facility of the Department of Immunology of the Institute of Biomedical Sciences (ICB/USP) maintains breeding SPF animals by strict hygienic barriers. Environmental conditions, husbandry, and the introduction of newly acquired animals are routinely controlled by trained technicians. The facility maintains isogenic and genetically modified mouse strains, primarily immunodeficient strains. There is also a self-contained quarantine area, where conventional animals received from different research institutions are maintained for rederivation and posterior transference to the SPF unit area. Animals are housed in individually ventilated polysulfide cages with pine wood shavings as bedding material in ventilated shelves with absolute filter (Alesco, São Paulo, Brazil). Animal handling is performed at a laminar airflow cabinet. All materials and supplies are autoclaved before use. Personnel shower and wear sterilized uniform, mask, cap, gloves and overshoes before entry. There is a unidirectional workflow to reduce cross-contamination between areas. Ambient conditions are maintained with ventilation and exhaustion at a minimum of 20 air changes/hour, temperature of $22^{\circ} \mathrm{C} \pm 2$, and relative humidity of $50 \% \pm 5$. A $12 \mathrm{hlight} /$ dark cycle is maintained, with lights off abruptly at 19:00 h. Commercial pelletized maintenance diet for rodents (Nuvilab-CR1, Quimtia S.A., Paraná, Brazil) and acidified water are provided ad libitum.

All husbandry procedures are performed in accordance with Brazilian legislation for the care and use of animals in research and educational activities. The number of animals and experimental procedures used in this paper were approved by the Institutional Ethics Committee on Animal Use (protocol number CEUA FMVZ/USP 4733231214). 


\section{Vasectomized males group}

Vasectomy was performed in $08 \mathrm{~B} 6 \mathrm{CBAF} 1$ and $06 \mathrm{CD} 1$ males at 8 weeks of age provided by ICB/USP facility. The anesthesia was induced by acepromazine $0.2 \%$, $2 \mathrm{mg} / \mathrm{kg}$ dose, ketamine hydrochloride 10\%, $100 \mathrm{mg} / \mathrm{kg}$ dose, and xylazine hydrochloride $2 \%, 10 \mathrm{mg} / \mathrm{kg}$ dose, intraperitoneally (IP). Sterile saline solution was used to prevent corneal drying during the surgery. Under general anesthesia, animals were laid in dorsal recumbency in a digital heating plate at $37^{\circ} \mathrm{C}$. Povidone-iodine solution was used in preoperative preparation of the skin and hair removal was performed with a razor. A $0.5 \mathrm{~cm}$ incision was made in the scrotal sac, and a small section of the vas deferens was cauterized by heated fine forceps. After the surgical procedure, a single dose of $5 \mathrm{mg} / \mathrm{kg}$ tramadol hydrochloride was administered subcutaneously. The mice were kept warm at $37^{\circ} \mathrm{C}$ until anesthesia recovery. After 2 weeks, these males were put in contact with B6CBAF1 females to test the vasectomy effectiveness. Females were observed for 2 weeks for detection of a possible pregnancy. After the first year, these animals were completely replaced by other 14 B6CBAF1 vasectomized males.

\section{Reagents}

Reagents used were pregnant mare's serum gonadotropin (PMSG, Sigma, G4877), human chorionic gonadotropin (hCG, Sigma, C1063), medium for embryo manipulation (M2 with HEPES, Sigma, M7167), and penicillin-streptomycin antibiotic (Pen-Strep $100 \mathrm{x}$, Sigma, P4333). The hormones were diluted in sterile phosphate-buffered saline solution to a final concentration of $50 \mathrm{IU} / \mathrm{ml}$ and frozen in $1-\mathrm{mL}$ aliquots at $-20^{\circ} \mathrm{C}$. M2 medium was supplemented with $500 \mu \mathrm{l}$ of Pen-Strep for each $50 \mathrm{~mL}$ of medium and sterilized with $0.22 \mu \mathrm{m}$ syringe filter. The medium was stored in a refrigerator between $2-8^{\circ} \mathrm{C}$.

\section{Female mice embryo donors group}

Twenty genetically modified mouse strains with undefined sanitary status from different research and education institutions were submitted to rederivation. Table 1 shows the designations of the strains.

In total, 160 female mice were mated. The hormone administration procedures, mating, and collection of oviducts from donors were performed by technicians who did not have contact with the SPF facility. The female mice were super ovulated by administration of 5 IU of PMSG, IP, per female between 12:00 and 14:00. After 48 h, 5 IU of hCG was injected following the random mating with male mice of the same strain. At 0.5 day-post-coitum (d.p.c.), female mice with copulatory plug were separated into groups up to 5 per cage.

\section{Collection of oviducts and embryo flushing}

At 1.5 d.p.c., female donors were submitted to euthanasia by cervical dislocation, the abdominal cavity was opened, and oviducts were aseptically collected. These were sent to the SPF facility and then placed in disposable petri dishes.

Table 1 - Designation of mouse strains submitted to rederivation by embryo transfer at the isogenic mouse facility (São Paulo, Feb. 2018)

\begin{tabular}{|c|c|}
\hline Mouse strain abbreviated designation & Mouse strain international designation \\
\hline B6 BKO & B6.129S2-Ighm TMICGN \\
\hline B6 CD11c-YFP & B6.Cg-Tg(Itgax-Venus) $1 \mathrm{Mnz}$ \\
\hline B6 OT II & B6.Cg-Tg(TcraTcrb)425Cbn \\
\hline 129 Sv PKR & 129-Eif2ak2 $2^{\mathrm{tm} 1 \mathrm{Cwe}}$ \\
\hline B6 Dectin- 1 & B6.129-Clec $7 a^{T M 1 G D b}$ \\
\hline B6 PUMA & $\mathrm{B} 6.129 \mathrm{P} 2-\mathrm{Bbc} 3^{\text {TM1GPZ }}$ \\
\hline B6 CD45.1 & B6.SJL-Ptprca Pepcb/BoyJ \\
\hline B6 ATG7RosaCreR & B6.TT2F-Atg7 ${ }^{\mathrm{tM} 1(\mathrm{CRE} / \mathrm{ERT} 2) \mathrm{TCHI}}$ \\
\hline B6 Bim & 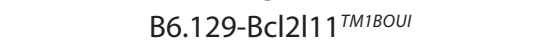 \\
\hline B6 lpr & B6.MRL-Fas ${ }^{L P R}$ \\
\hline B6 TLR-4 & B6.129-TIr4 $4^{\text {TMIAKI }}$ \\
\hline B6 PAFR & B6.129P2-Ptafr TM1TKSh \\
\hline B6 Galectina & B6. Cg-Lgals1 $1^{\text {TM1ROB } / J}$ \\
\hline B6 XPC & $\mathrm{B} 6 ; 129-X p c^{T M 1 E C F} / \mathrm{J}$ \\
\hline B6 P2RX7 & B6.129P2-P2rx $7^{\text {TM1GAB }}$ \\
\hline B6 Perforina & B6.129-pfn-TMICLRK \\
\hline K $14-64 / C S A$ & K $14-64 / C S A$ \\
\hline K 14-64 (+) /XPC (-/-) & K 14-64 (+) /XPC (-/-) \\
\hline B6 Caspase 1 & B6N.129S2-Casp $1^{\text {TM1FLV } / J}$ \\
\hline B6 ASC 1 & B6;129P2-Slc7a10 TM1DGEN/H \\
\hline
\end{tabular}


Embryos were flushed from oviducts using M2 medium and collected in pool with a mouth transfer capillary setup under stereoscopic microscope (SMZ-10, Nikon). Embryos in two-cell with intact zona pellucida were washed 10 times in M2 medium with 100-fold dilutions between each wash, with a fresh glass pipette used to transfer embryos through each wash. The transfer capillary setup followed available literature (Nagy et al., 2003).

\section{Recipients and embryo transfer}

Recipients consisted of 36 SPF female mice, nulliparous, B6CBAF1 (hybrid), B.10A (isogenic), and CD1 (heterogenic), provided by ICB/USP facility. Three and a half days before mating, recipients were exposed to urine from the vasectomized males for estrous cycle synchronization (Whitten, 1956). Each female was mated with a vasectomized male close to the end of the light cycle period. Mating was performed for obtaining pseudo-pregnancies (Bronson et al., 1966). Embryo transfers were performed at 0.5 d.p.c. in recipient females with copulatory plug. Surgeries were performed within the SPF facility clean area under a horizontal laminar flow cabinet (FUH-09, Veco, São Paulo, Brazil). Females were anesthetized with the same protocol used in vasectomized males. Each female was placed on a dry tissue on a heating digital plate at $37^{\circ} \mathrm{C}$ in ventral recumbency. Povidone-iodine solution was used in preoperative preparation of the skin and hair removal was performed with a razor in the region between the last rib and hind limbs. Skin was rinsed with $70 \%$ ethanol. An incision, $1 \mathrm{~cm}$ long, of the skin was made parallel to the dorsal midline. The peritoneal cavity was accessed via a musculature incision over the fat pad attached to the ovary, which was fixed with a vessel clamp. A stereoscopic microscope (SMZ 2-B, Nikon) was used to visualize the oviducts. A small incision was made in the bursa between ovary and oviduct to expose the infundibulum. Each female received between 10 and 30 two-cell embryos divided between oviducts with a glass micropipette. The skin incision was closed with nylon 4-0 sutures using simple interrupted stitches. A total of 625 embryos were transferred into the recipients. After 3 weeks, we observed births, and at 21 days of age, pups were weaned.

\section{Health screening and genetic control}

Health screening was performed in the following groups: sentinels from the quarantine area, recipients after weaning of pups, and SPF sentinels exposed for a period of 12 weeks to soiled bedding during the routine cage change from SPF colony. Antibody detection was performed by enzyme-linked immunosorbent assay (ELISA) for murine hepatitis virus (MHV), minute virus of mice (MVM), Theiler virus (TMEV, GDVII), reovirus 3, ectromelia, pneumonia virus mouse, Sendai virus, parvovirus (MPV-1), lymphocytic choriomeningitis virus (LCMV), adenovirus (MAV), rotavirus (EDIM), norovirus (MNV), and Mycoplasma spp. For bacterial flora evaluation, biological material was collected from the respiratory and digestive tracts, followed by cultivation in selective and non-selective growth mediums, in aerobic and anaerobic conditions. Bacteria identification was performed by EPM-Mili (Probac, São Paulo, Brazil), Bactray I, II and III, and BBL Crystal (Laborclin, Paraná, Brazil). Research for Proteus mirabilis was made from the bronchoalveolar flushing and feces pool, with identification by enterobacteria kits. Detection of acariasis was performed by direct examination of the fur by stereomicroscopy. Diagnosis of internal parasites and intestinal protozoa was accomplished by perianal tape test, fecal flotation, centrifugation, and examination of fecal and colonic content. The list from researched agents followed recommendations for monitoring laboratory mice according to the Federation of European Laboratory Animal Science Associations - FELASA (Mähler et al., 2014).

The genetic control was targeted for each specific strain mutation, performed in pups after weaning. The DNA was extracted by tail tip biopsies from each pup, followed by its amplification in the thermocycler and identification in agarose gel. Genotyping protocols are available at The Jackson Laboratory (2018) website.

\section{Data collection}

The data were obtained from the facility routine within a time span of 3 years. No comparative studies regarding the reproductive outcomes between donors were accomplished due to genotypic differences between strains, nor did we perform any tests in control group.

\section{Results}

\section{Health screening}

In quarantine area, we detected positive serology for murine hepatitis virus (MHV) in $37 \%$ of animals, and for norovirus (MNV) in 30\%. Bacteria were found in the oropharyngeal tract, such as Corynebacterium kutscheri (5\%), Staphylococcus aureus (42\%), beta hemolytic Streptococcus (5\%), and Bordetella bronchiseptica (5\%). Proteus mirabilis was detected in feces culture in $5 \%$ of tested animals. The following protozoan were also detected: Tritrichomonas minuta (5\%), Tritrichomonas muris (11\%), and Chilomastix 
bettencourti (11\%). Table 2 shows the results of sanitary control before rederivation. Female recipients did not show any of the infectious agents previously detected in quarantined animals. Proteus mirabilis was detected only in SPF sentinels (9\%) exposed to soiled bedding of SPF colony. Table 3 shows the results from health screening after rederivation.

\section{Genetic control}

All pups presented the strain-specific mutation in homozygosis and heterozygosis, which allowed the formation of new foundation pairs. Data not shown.

\section{Reproductive performance of genetically modified mouse strains}

Twenty strains were submitted to rederivation. From these, 18 were successfully rederived. Table 4 shows the reproductive outcome: a total of 881 embryos were obtained, and of these, 625 embryos at two-cell stage. The B6 CD45.1 strain presented the highest fertility rate, at $81 \%$, and the $\mathrm{K} 14-64(+) / \mathrm{XPC}(-/-)$ strain presented the lowest fertility rate, at $9 \%$. The fertility rate was obtained by the sum of two-cell embryos divided by total of cells (two-cells, fragmented and unfertilized oocytes). The total number of live births was 148, and from these, 65 males

Table 2 - Results of sanitary control performed in sentinels from quarantine area before embryo transfer rederivation (São Paulo, Feb. 2018)

\begin{tabular}{lcc}
\hline \multicolumn{1}{c}{ Pathogens } & Sample & $\begin{array}{c}\text { Number of positive sentinels/numbers } \\
\text { tested (\%) }\end{array}$ \\
\hline $\begin{array}{l}\text { Viruses }{ }^{1)} \\
\text { Mouse hepatitis virus (MHV) }\end{array}$ & Serum & $7 / 19(37 \%)$ \\
Norovirus (MNV) & Serum & $3 / 10(30 \%)$ \\
Bacteria & & $1 / 19(5 \%)$ \\
Corynebacterium kutscheri & Oropharynx & $8 / 19(42 \%)$ \\
Staphylococcus aureus & Oropharynx & $1 / 19(5 \%)$ \\
Streptococci beta hemolytic & Oropharynx & $1 / 19(5 \%)$ \\
Bordetella bronchiseptica & Oropharynx & $1 / 19(5 \%)$ \\
Proteus mirabilis ${ }^{2)}$ & Oropharynx/intestinal tract/feces & $1 / 19(5 \%)$ \\
Intestinal protozoan & & $2 / 19(11 \%)$ \\
Tritrichomonas minuta & & $2 / 19(11 \%)$ \\
Tritrichomonas muris & Intestinal tract/feces & \\
Chilomastix bettencourti & Intestinal tract/feces & \\
\hline Key: ${ }^{\prime \prime}$ Intestinal tract/feces & \\
\hline
\end{tabular}

Key: ${ }^{1)}$ The animals presented negative results for the following virus agents: Ectromelia virus (0/19), Theiler's virus (0/19), MVM (0/19), PVM (0/19), REO-3 $(0 / 19)$, Sendai virus (0/19), MPV (0/19), LCMV (0/19), MAV (0/19), MRV (0/19). ${ }^{2}$ Pathogen found only in feces culture.

Table 3 - Results of sanitary control performed in recipients after embryo transfer rederivation and sentinels exposed to soiled bedding from SPF colony (São Paulo, Feb. 2018)

\begin{tabular}{|c|c|c|c|}
\hline Pathogens ${ }^{1)}$ & Sample & $\begin{array}{c}\text { Number of positive recipients/ } \\
\text { numbers tested (\%) }\end{array}$ & $\begin{array}{c}\text { Number of positive sentinels/ } \\
\text { numbers tested (\%) }\end{array}$ \\
\hline \multicolumn{4}{|l|}{ Viruses } \\
\hline Mouse hepatitis virus (MHV) & Serum & $0 / 12$ & $0 / 10$ \\
\hline Norovirus (MNV) & Serum & $N T^{21}$ & $0 / 10$ \\
\hline Parvovirus (MPV) & Serum & $0 / 12$ & $0 / 10$ \\
\hline \multicolumn{4}{|l|}{ Bacteria } \\
\hline Corynebacterium kutscheri & Oropharynx & $0 / 14$ & $0 / 11$ \\
\hline Staphylococcus aureus & Oropharynx & $0 / 14$ & $0 / 11$ \\
\hline Streptococci beta hemolytic & Oropharynx & $0 / 14$ & $0 / 11$ \\
\hline Bordetella bronchiseptica & Oropharynx & $0 / 14$ & $0 / 10$ \\
\hline Proteus mirabilis & Oropharynx/intestinal tract/feces & $0 / 14$ & $1 / 11^{3)}$ \\
\hline \multicolumn{4}{|l|}{ Intestinal protozoan } \\
\hline Tritrichomonas minuta & Intestinal tract/ feces & $0 / 14$ & $0 / 10$ \\
\hline Tritrichomonas muris & Intestinal tract/ feces & $0 / 14$ & $0 / 10$ \\
\hline Chilomastix bettencourti & Intestinal tract/ feces & $0 / 14$ & $0 / 10$ \\
\hline
\end{tabular}

Key: ${ }^{1)}$ The animals presented negative results for other agents recommended by FELASA. ${ }^{2)}$ NT: Not tested; ${ }^{3)}$ Pathogen found only in feces culture 
Table 4 - Reproductive outcome from genetically modified mouse strains submitted to embryo transfer rederivation (São Paulo, Feb.2018)

\begin{tabular}{|c|c|c|c|}
\hline \multirow{2}{*}{$\frac{\text { Strain }}{\text { Female mice (n) }}$} & \multirow{2}{*}{$\begin{array}{c}\text { Fertility rate } \\
\text { Number of two-cell embryos/ } \\
\text { total number of embryos }{ }^{11}(\%)\end{array}$} & \multicolumn{2}{|c|}{ Embryo transfer } \\
\hline & & Number of recipients & $\begin{array}{c}\text { Number of pups born/number } \\
\text { of transferred embryos }{ }^{2)}(\%)\end{array}$ \\
\hline B6 BKO (9) & $62 / 121(51)$ & 2 & $17 / 40(43)$ \\
\hline B6 CD11c-YFP (5) & $15 / 44(34)$ & 1 & $8 / 15(53)$ \\
\hline В6 OT II (5) & $27 / 51(53)$ & 1 & $11 / 20(55)$ \\
\hline 129 Sv PKR (5) & 68/103 (66) & 2 & $15 / 40(38)$ \\
\hline B6 PUMA (4) & 9/14 (64) & 1 & $6 / 9(67)$ \\
\hline B6 CD45.1 (3) & $34 / 42(81)$ & 1 & $13 / 20(65)$ \\
\hline B6 ATG7RosaCreR (5) & 29/54 (54) & 1 & $8 / 20(40)$ \\
\hline B6 Bim (6) & $48 / 118(41)$ & 2 & $12 / 40(30)$ \\
\hline B6 Dectin- 1 (4) & $58 / 91(64)$ & 2 & $5 / 40(13)$ \\
\hline B6 Ipr (7) & $35 / 109(32)$ & 2 & $5 / 35(14)$ \\
\hline B6 PAFR (12) & $123 / 245(50)$ & 3 & $3 / 60(5)$ \\
\hline B6 TLR-4 (3) & $39 / 75(52)$ & 2 & $5 / 39(13)$ \\
\hline B6 Galectina (5) & 66/95 (69) & 1 & $5 / 20(25)$ \\
\hline B6 XPC (7) & $33 / 67$ (49) & 2 & $0 / 33(0)$ \\
\hline B6 P2RX7 (3) & $28 / 53(53)$ & 2 & $3 / 28(11)$ \\
\hline B6 Perforina (4) & $34 / 44(77)$ & 2 & 10/34 (29) \\
\hline K14-64/CSA (5) & $53 / 89(60)$ & 3 & $0 / 53(0)$ \\
\hline K14-64 (+) /XPC (-/-) (5) & 7/77 (9) & 1 & $3 / 7(43)$ \\
\hline B6 Caspase (5) & 61/113 (54) & 1 & $11 / 20(55)$ \\
\hline B6 ASC (5) & $52 / 97(54)$ & 4 & $8 / 52(15)$ \\
\hline
\end{tabular}

Key: ${ }^{1)}$ Total number of embryos in two-cell, fragmented eggs and unfertilized oocytes. ${ }^{2)}$ Number of transferred embryos were performed accordingly to the number of recipients available.

and 75 females were weaned. B6 XPC and K14-64/CSA strains did not present births.

\section{Discussion}

Rederivation by embryo transfer demonstrated to be an efficient technique for eliminating infectious agents previously found in animals maintained in the quarantine area. The results obtained in our practice may be compared to what has been found at other international animal facilities to obtain SPF rodents (Van Keuren \& Saunders, 2004; Amstislavsky et al., 2013).

Antibodies against MHV were not detected in female recipients after rederivation, resembling data found in the literature. In experimental conditions in which the embryos were exposed to MHV, neither recipients nor pups showed seroconversion after proper washing procedures and embryo transfer (Carthew et al., 1985; Mahabir et al., 2007). In view of the large number of immunodeficient strains bred in our animal facility, the presence of MHV would promote dissemination and persistent transmission of the virus throughout the colony (Rehg et al., 2001). Moreover, MHV infection can lead to numerous effects on host physiology and severely compromise the value of these animals for research purposes (Baker, 1998).

According to rederivation outcomes, embryo transfer also avoided the introduction of animals infected by norovirus in the SPF facility. This virus is considered the most prevalent infectious agent in laboratory mouse facilities and, due to its high capacity of dissemination, compromises not only immunodeficient mice but also healthy animals (Henderson, 2008; Rodrigues et al., 2017). Zhang (2008) has found norovirus in semen, oocytes, and embryos; thus, there is a risk of transmission of the virus to the recipient and its offspring. Fortunately, this risk seems to be minimal and rederivation has been efficient at eliminating norovirus, which corroborates our results (Artwohl et al., 2008; Raspa et al., 2016).

There are discussions in literature about the transmission potential of some infectious agents from embryos to recipients, especially some viruses, such as mouse parvoviruses and cytomegalovirus (Besselsen et al., 2008; Tsutsui et al., 1995). These viruses have high prevalence among laboratory animal facilities and biological materials. We have not found these agents in our facility; nonetheless, we consider it important to emphasize that these agents may be detected in gametes, embryos and ovarian tissues (Agca et al., 2007). According to Van Soom et al. (2010), embryo transfer is the safest way to move genetic material from one facility to another between countries. In this regard, biosecurity measures preconized by the International Embryo Technology Society (IETS) and by the World Organisation for Animal Health (OIE) must be correctly followed (Stringfellow, 1998; Stringfellow \& Givens, 2000; World Organisation for Animal Health, 2016). 
The sanitary barriers in an SPF facility exceed those required for the introduction of new mouse strains. Standard operating procedures are adopted, such as the use of contaminant-free materials and supplies, with the addition of periodic screening of animal health. We found in sentinels the infectious opportunistic agent, Proteus mirabilis, which could affect immunodeficient mouse strains (Jones et al., 1972; Maronpot \& Peterson, 1981; Scott, 1989). Proteus mirabilis has been sporadically detected in the colony at low rates. It could be eliminated by rederivation into recipients free of opportunistic and specific pathogens (SOPF).

The genetic control was done to determine possible incorrect mating of donor animals and changes in the phenotype described in few mutant strains after rederivation. According to a review by Franklin (2006), the disease manifestation may be considerably distinct in a genetically modified mouse and in an isogenic or heterogenic animal. This happens because induced mutations may modify host susceptibility to microbial infections. As a result, the infection may alter the phenotype of a mutant mouse and confound the results and conclusions on the altered gene function. Correct genetic information from the mutant strains received is of fundamental importance since many mutations may exist for the same gene. The introduction of mouse strains into breeding animal facilities with incomplete or nonexistent information occurs frequently, and the genetic control is not always performed, negatively impacting the animal facility and researchers.

Fertility rates from embryo donors varied between strains. Females that demonstrated fertility rates less than $50 \%$, such as B6 CD11c-YFP, B6 Bim, and B6 lpr, also showed low productivity rates in breeding performance. In our opinion, birth rates lower than $50 \%$ could be taken as a disadvantage condition for the rederivation. We did not observe births in two strains. Our hypothesis is that some strains might be more fragile to embryo manipulation and to other events related to the technique. These points could be subjects of future studies. The observed events regarding the individual response of each strain to artificial hormonal ovulation and birth rates could be attributed to genetic differences inherent to each strain, age, and female weight (Nagy et al., 2003; Byers et al., 2006; Luo et al., 2011; Bortolatto et al., 2012).

Embryo transfer is considered a well-established technique to rederive infected mice colony. However, there were some aspects that required more attention during establishment of this technique. The high skill requirements can be considered a limiting factor. Some studies provide alternatives with good results for the execution of embryo transfer using modified transfer pipettes or diversified methodologies, including the transfer of embryos in more advanced stages (Davis, 1981; Chin \& Wang, 2001; Zhang et al., 2009; Sarvari et al., 2013; Cui et al., 2014). In our opinion, we considered that routine practice and appropriate training contributed to the acquisition of necessary skills for the surgical technique.

Other challenges faced during the rederivation program were the availability of a trained and coordinated staff, proper space for maintenance of vasectomized males, recipients and donors, adequate equipment, including equipment for embryo cryopreservation, availability of quality supplies, and the incurred costs for health screening and mouse husbandry. There was also the concern of providing animals to the researchers in the shortest time span possible. In our experience, time span for rederivation took from 6 months to 1 year.

Diversity between animal facilities and between the microenvironment of isolated cages within the same facility leads to conflicting results in experimental animal model (Macpherson \& Mccoy, 2015). To investigate role of gut microbiota on animal model phenotypes, researchers need methods to experimentally manipulate it. Interestingly, embryo transfer may have a potential usefulness to study interactions between host and microbiota, because pups generated via embryo transfer acquire the microbiota of surrogate mothers (Ericsson \& Franklin, 2015).

Finally, due to the increase in the number of genetically modified mice strains and the consequent increase of animal transfer between facilities, the use of embryos would be a safer and more economical alternative for obtaining new mice models. In addition, the use of embryos would reduce the number of live animals required for strain maintenance because these could be cryopreserved for an unlimited time (Crabbe et al., 1993; Rall et al., 2000; Wayss et al., 2005; Hagn et al., 2007; Amstislavsky et al., 2016).

\section{Conclusion}

In conclusion, rederivation of mouse strains by embryo transfer demonstrated to be an efficient tool for obtaining SPF animals. The use of SPF mice reduces the number of animals required for each study and promotes refinement in animal well-being. Our results indicate that embryo transfer is a feasible and cost-effective method for rederivation. In addition, the improvement of sanitary conditions of rederived strains allowed the expansion of these strains in our SPF foundation and, consequently, the distribution of better experimental models for the scientific community. 


\section{Conflict of interests}

The authors declare that they have no conflict of interest.

\section{Ethics Statement}

The protocol for the experimental study was approved by the animal ethics committee of the institution, number 4733231214 (FMVZ-USP). We followed the Brazilian guidelines established by the National Council for the Control of Animal Experimentation (CONCEA) which

\section{References}

Agca Y, Bauer BA, Johnson DK, Critser JK, Riley LK. Detection of mouse parvovirus in Mus musculus gametes, embryos, and ovarian tissues by polymerase chain reaction assay. Comp Med. 2007;57(1):51-6. PMid:17348291.

Amstislavsky SY, Brusentsev EY, Abramova TO, Ragaeva DS, Rozhkova IN, Igonina TN, Kizilova EA, Naprimerov VA, Feoktistova NY. Applying reproductive technologies and genome resource banking to laboratory animals. Russ J Genet. 2016;6(4):373-7. http://dx.doi.org/10.1134/ S2079059716040031.

Amstislavsky SY, Igonina TN, Rozhkova IN, Brusentsev EY, Rogovaya AA, Ragaeva DS, Naprimerov VA, Litvinova EA, Plyusn Ina IF, Markel AL. Rederivation by embryo transfer in strains of laboratory mice and rats. Russ J Genet. 2013;3(4):305-15. http://dx.doi.org/10.1134/ S2079059713040023.

Artwohl JE, Purcell JE, Fortman JD. The use of cross-foster rederivation to eliminate murine norovirus, Helicobacter spp., and murine hepatitis virus from a mouse colony. J Am Assoc Lab Anim Sci. 2008;47(6):19-24. PMid:19049248.

Baker DG. Natural pathogens of laboratory mice, rats, and rabbits and their effects on research. Clin Microbiol Rev. 1998;11(2):231-66. http://dx.doi.org/10.1128/CMR.11.2.231. PMid:9564563.

Besselsen DG, Romero-Aleshire MJ, Munger SJ, Marcus EC, Henderson KS, Wagner AM. Embryo transfer rederivation of C.B-17/Icr-Prkdcscid mice experimentally infected with mouse parvovirus 1. Comp Med. 2008;58(4):353-9. PMid:18724777.

Bortolatto J, Bom J, Motta MC, Cruz RJ, Ferreira FM, Silva SVB, Massiorini S, Chammas R, Lima RD, Russo M. Núcleo de desenvolvimento em fertilização in vitro. Revista da Sociedade Brasileira da Ciência em Animais de Laboratório. 2012;1(1):14-23. are like those in the Guide for Care and Use of Laboratory Animals of the US National Research Council.

\section{Acknowledgements}

The authors thank Professors Momtchilo Russo, Niels Olsen Saraiva Câmara, Ana Paula Lepique and Caroline Ferreira Marcantonio. We also thank animal technicians of ICB's Department of Immunology.

Bronson FH, Dagg CP, Snell GD. Biology of the laboratory mouse. New York: Dover Publications; 1966.

Byers SL, Payson SJ, Taft RA. Performance of ten inbred mouse strains following assisted reproductive technologies (ARTs). Theriogenology. 2006;65(9):1716-26. http://dx.doi. org/10.1016/j.theriogenology.2005.09.016. PMid:16271754.

Carthew P, Wood MJ, Kirby C. Pathogenicity of mouse hepatitis virus for preimplantation mouse embryos. J Reprod Fertil. 1985;73(1):207-13. http://dx.doi.org/10.1530/ jrf.0.0730207. PMid:2982018.

Chin HJ, Wang C-KL. Utero-tubal transfer of mouse embryos. Genesis. 2001;30(2):77-81. http://dx.doi.org/10.1002/ gene.1036. PMid:11416867.

Compton SR. Prevention of murine norovirus infection in neonatal mice by fostering. J Am Assoc Lab Anim Sci. 2008;47(3):25-30. PMid:18459709.

Crabbe JC, Schneider U, Hall JW, Mazur P. Invited commentary: cryopreservation as a tool for the study of selectively bred lines in rodent behavioral genetics. Behav Genet. 1993;23(4):307-12. http://dx.doi.org/10.1007/ BF01067430. PMid:8240209.

Cui L, Zhang Z, Sun F, Duan X, Wang M, Di K, Li X. Transcervical embryo transfer in mice. J Am Assoc Lab Anim Sci. 2014;53(3):228-31. PMid:24827563.

Davis T. Nonsurgical transfer of mouse embryos. Bios. 1981;52(3):127-33.

Ericsson AC, Franklin CL. Manipulating the gut microbiota: methods and challenges. ILAR J. 2015;56(2):205-17. http:// dx.doi.org/10.1093/ilar/ilv021. PMid:26323630. 
Franklin CL. Microbial considerations in genetically engineered mouse research. ILAR J. 2006;47(2):141-55. http://dx.doi.org/10.1093/ilar.47.2.141. PMid:16547371.

Fray MD, Pickard AR, Harrison M, Cheeseman MT. Upgrading mouse health and welfare: direct benefits of a large-scale rederivation programme. Lab Anim. 2008;42(2):127-39. http://dx.doi.org/10.1258/la.2007.007005. PMid:18435871.

Glage S, Dorsch M, Hedrich HJ, Bleich A. Rederivation of Helicobacter hepaticus-infected Mongolian gerbils by Caesarean section and cross-fostering to rats and mice. Lab Anim. 2007;41(1):103-10. http://dx.doi. org/10.1258/002367707779399437. PMid:17234056.

Hagn M, Marschall S, Angelis MH. The European mouse mutant archive. Brief Funct Genomics. 2007;6(3):186-92. http://dx.doi.org/10.1093/bfgp/elm018.

Henderson KS. Murine norovirus, a recently discovered and highly prevalent viral agent of mice. Lab Anim. 2008;37(7):314-20. http://dx.doi.org/10.1038/laban0708-314. PMid:18568010.

Inzunza J, Midtvedt T, Fartoo M, Norin E, Osterlund E, Persson A-K, Ahrlund-Richter L. Germfree status of mice obtained by embryo transfer in an isolator environment. Lab Anim. 2005;39(4):421-7. http://dx.doi. org/10.1258/002367705774286439. PMid:16197709.

Janus LM, Smoczek A, Hedrich H, Bleich A. Risk assessment of minute virus of mice transmission during rederivation: detection in reproductive organs, gametes, and embryos of mice after in vivo infection. Biol Reprod. 2009;81(5):10105. http://dx.doi.org/10.1095/biolreprod.109.076968. PMid:19553599.

Jones JB, Estes PC, Jordan AE. Proteus mirabilis infection in a mouse colony. J Am Vet Med Assoc. 1972;161(6):6614. PMid:4560278.

Luo C, Zuñiga J, Edison E, Palla S, Dong W, Parker-Thornburg J. Superovulation strategies for 6 commonly used Mouse strains. J Am Assoc Lab Anim Sci. 2011;50(4):471-8. PMid:21838974.

Macpherson AJ, Mccoy K. Standardised animal models of host microbial mutualism. Mucosal Immunol. 2015;8(3):47686. http://dx.doi.org/10.1038/mi.2014.113. PMid:25492472.

Mahabir E, Bauer B, Schmidt J. Rodent and germplasm trafficking: risks of microbial contamination in a high-tech biomedical world. ILAR J. 2008;49(3):347-355. http://dx.doi. org/10.1093/ilar.49.3.347. PMid:18506068.
Mahabir E, Bulian D, Needham J, Mayer A, Mateusen B, Van Soom A, Nauwynck H, Schmidt J. Transmission of Mouse Minute Virus (MMV) but not Mouse Hepatitis Virus (MHV) following embryo transfer with experimentally exposed in vivo-derived embryos. Biol Reprod. 2007;76(2):189-97. http:// dx.doi.org/10.1095/biolreprod.106.056135. PMid:17021342.

Mähler M, Berard M, Feinstein R, Gallagher A, IllgenWilcke B, Pritchett-Corning K, Raspa M. FELASA recommendations for the health monitoring of mouse, rat, hamster, guinea pig and rabbit colonies in breeding and experimental units. Lab Anim. 2014;48(3):178-92. http:// dx.doi.org/10.1177/0023677213516312. PMid:24496575.

Maronpot RR, Peterson LG. Spontaneus proteus nephritis among male C3H/HeJ mice. Lab Anim Sci. 1981;31(6):697700. PMid:7045517.

Morrell JM. Techniques of embryo transfer and facility decontamination used to improve the health and welfare of transgenic mice. Lab Anim. 1999;33(3):201-6. http:// dx.doi.org/10.1258/002367799780578165. PMid:10780837.

Nagy A, Gertsenstein M, Vintersten K, Behringer R. Manipulating the mouse embryo: a laboratory manual. New York: Cold Spring Harbor Laboratory Press; 2003. 764 p.

Nicklas W, Keubler L, Bleich A. Maintaining and monitoring the defined microbiota status of gnotobiotic rodents. ILAR J. 2015;56(2):241-9. http://dx.doi.org/10.1093/ilar/ilv029. PMid:26323633.

OIE: World Organisation for Animal Health. Terrestrial animal health code. Paris: OIE; 2016. Chapter 4.10, Collection and processing of laboratory rodent and rabbit embryos/ova; p. 1-6.

Rall WF, Schmidt PM, Lin X, Brown SS, Ward AC, Hansen CT. Factors affecting the efficiency of embryo cryopreservation and rederivation of rat and mouse models. ILAR J. 2000;41(4):221-7. http://dx.doi.org/10.1093/ilar.41.4.221. PMid:11123182.

Raspa M, Mahabir E, Fray M, Volland R, Scavizzi F. Lack of transmission of murine norovirus to mice via in vitro fertilization, intracytoplasmic sperm injection, and ovary transplantation. Theriogenology. 2016;86(2):579-88. http://dx.doi.org/10.1016/j.theriogenology.2016.02.008. PMid:26972226.

Reetz IC, Wullenweber-Schmidt M, Kraft V, Hedrich HJ. Rederivation of inbred strains of mice by means of embryo transfer. Lab Anim Sci. 1988;38(6):696-701. PMid:2851686. 
Rehg JE, Blackman MA, Toth LA. Persistent transmission of mouse hepatitis virus by transgenic mice. Comp Med. 2001;51(4):369-74. PMid:11924797.

Rodrigues DM, Moreira JCO, Lancellotti M, Gilioli R, Corat MAF. Murine norovirus infection in Brazilian animal facilities. Exp Anim. 2017;66(2):115-24. http://dx.doi. org/10.1538/expanim.16-0027. PMid:28049885.

Rouleau AM, Kovacs PR, Kunz HW, Armstrong DT. Decontamination of rat embryos and transfer to specific pathogen-free recipients for the production of a breeding colony. Lab Anim Sci. 1993;43(6):611-5. PMid:8158990.

Russel WMS, Burch RL. The principles of humane experimental technique. London: Wheathampstead; 1959.

Sarvari A, Naderi MM, Sadeghi MR, Akhondi MM. A technique for facile and precise transfer of mouse embryos. Avicenna J Med Biotechnol. 2013;5(1):62-5. PMid:23626878.

Scott R. Fatal Proteus mirabilis infection in a colony scid/ bg immunodeficient mice. Lab Anim Sci. 1989;39:470-1.

Stehr M, Greweling MC, Tischer S, Singh M, Blöcker H, Monner DA, Müller W. Charles River altered Schaedler flora (CRASF) remained stable for four years in a mouse colony housed in individually ventilated cages. Lab Anim. 2009;43(4):362-70. http://dx.doi.org/10.1258/la.2009.0080075. PMid:19535393.

Stringfellow DA, Givens MD. Preventing disease transmission through the transfer of in-vivo- derived bovine embryos. Livest Prod Sci. 2000;62(3):237-51. http://dx.doi.org/10.1016/ S0301-6226(99)00160-8.

Stringfellow DA. Recommendations for the sanitary handling of in vivo derived embryos. In: Stringfellow DA, Seidel SM. Manual of the International Embryo Transfer Society. Savoy: IETS; 1998. p. 79-84.

The Jackson Laboratory. Jax ${ }^{\circledR}$ mouse search. Bar Harbor: Jax; 2018 [cited 2018 Oct 19]. Available from: https://www. jax.org/mouse-search.

Tsutsui Y, Kashiwai A, Kawamura N, Aiba-Masago S, Kosugi I. Prolonged infection of mouse brain neurons with murine cytomegalovirus after pre- and perinatal infection. Arch Virol. 1995;140(10):1725-36. http://dx.doi.org/10.1007/ BF01384337. PMid:7503674.

Van Keuren ML, Saunders TL. Rederivation of transgenic and gene-targeted mice by embryo transfer. Transgenic
Res. 2004;13(4):363-71. http://dx.doi.org/10.1023/ B:TRAG.0000040040.82536.a5. PMid:15517995.

Van Soom A, Wrathall AE, Herrler A, Nauwynck HJ. Is the zona pellucida an efficient barrier to viral infection? Reprod Fertil Dev. 2010;22(1):21-31. http://dx.doi.org/10.1071/ RD09230. PMid:20003842.

Watson J, Thompson KN, Feldman SH. Successful rederivation of contaminated immunocompetent mice using neonatal transfer with iodine immersion. Comp Med. 2005;55(5):465-9. PMid:16270904.

Watson JG, Wright RW Jr, Chaykin S. Collection and transfer of preimplantation mouse embryos. Biol Reprod. 1977;17(3):453-8. http://dx.doi.org/10.1095/biolreprod17.3.453. PMid:901897.

Wayss K, Klefenz M, Schenkel J. Cryopreservation of transgenic mouse embryos: an eight years' experience. J Exp Anim Sci. 2005;43(2):69-85. http://dx.doi.org/10.1016/j. jeas.2004.09.001.

Whitten WK. Modification of the oestrus cycle of the mouse by external stimuli associated with the male. J Endocrinol. 1956;13(4):399-404. http://dx.doi.org/10.1677/joe.0.0130399. PMid:13345955.

Zhang L. Microbial pathogen contamination in mouse gametes and embryos [thesis]. Columbia: University of Missouri; 2008. http://dx.doi.org/10.32469/10355/5671.

Zhang Z, Lv X, Wang Y, Chen Y, Zheng R, Sun H, Bian G, Xiao Y, Li Q, Yang Q, Ai J, Duan J, Tan R, Liu Y, Yang Y, Wei Y, Zhou Q. Success of murine embryo transfer increased by a modified transfer pipette. J Reprod Dev. 2009;55(1):94-7. http://dx.doi.org/10.1262/jrd.20090. PMid:19023181.

Funding: this study was funded by Institute of Biomedical Sciences (ICB/USP). Department of Immunology. University of São Paulo (USP), Brazil.

Authors Contributions: Ana Tada Fonseca Brasil Antiorio, Sílvia Maria Gomes Massironi, Rosália Regina De Luca, Márcio Augusto Caldas Rocha Carvalho, Vanessa Yamamoto Tambellini, Danilo Wadt, Juliana Bortolatto, Joana Bom and Claudia Madalena Cabrera Mori conceived, planned and carried out the experiments. Ana Tada Fonseca Brasil Antiorio wrote the manuscript with the support of Claudia Madalena Cabrera Mori. All authors contributed to the final manuscript. 